\title{
Anthrovision
}

Vaneasa Online Journal

1.2 | 2013

Varia

\section{Orientalism Today: Alive and Well}

Film Review: Himself He Cooks - A film by Valérie Berteau and Philippe Witjes, Belgium 2011

\section{Nandini Bedi}

\section{Q OpenEdition}

1 Journals

Electronic version

URL: http://journals.openedition.org/anthrovision/645

DOI: 10.4000/anthrovision.645

ISSN: 2198-6754

\section{Publisher}

VANEASA - Visual Anthropology Network of European Association of Social Anthropologists

\section{Electronic reference}

Nandini Bedi, «Orientalism Today: Alive and Well », Anthrovision [Online], 1.2 | 2013, Online since 02 August 2013, connection on 22 September 2020. URL : http://journals.openedition.org/anthrovision/ 645 ; DOI : https://doi.org/10.4000/anthrovision.645

This text was automatically generated on 22 September 2020

(c) Anthrovision 


\section{Orientalism Today: Alive and Well}

Film Review: Himself He Cooks - A film by Valérie Berteau and Philippe Witjes, Belgium 2011

\section{Nandini Bedi}

\section{EDITOR'S NOTE}

http://www.polymorfilms.be/\#/Films/Himself\%20He\%20Cooks/

Website with references on the film and the authors

1 It is not the first time in the Netherlands that I have sat at the edge of my seat drinking in the beauty of images made and woven together through a documentary film by 'Western eyes' looking at the land of my birth. Then slowly I have watched with growing apprehension what they choose to leave out of the frame and what they choose to put into it and how they do it.

2 I ask myself, 'Why do they continue to 'exoticise' India'?

3 A few days ago, I went to see a documentary made by two Belgian directors. It is called 'Himself he cooks'. It is shot in the Golden Temple of the Sikhs, in Amritsar, India, the most sacred place of worship for the community. This temple offers free food for a hundred thousand visitors every day and for double or triples that number on feast days. Visitors may also rest there during the day or night. Images of cooking, cleaning, serving and washing by thousands of volunteers dominate the film. To quote from the synopsis: 'the spontaneous choreography of the many hands that join in the preparation of the food reveals the essence of this fascinating place and invites the viewer to consider the joy of sharing'. The still image that accompanies this description in the brochure shows a devotee in the pool before the temple, head bowed in prayer, hands joined. Together the image and the description invite us to enter into that incomprehensible world of India, where we could once more be struck with wonder at its ever-surprising repertoire of religion, faith, worship and community. 'Himself he cooks' has been chosen as the opening film of the Beeld voor Beeld film festival in Amsterdam. 
We see garlic being chopped by crowds, potatoes peeled, tears rolling down the eyes of onion cutters while hands are in musical rhythm, balls of flour being flung to the ground and directed with a hoe, rotis being flipped with immaculate precision, metal plates flung from outside the frame at a man holding a plate like a bat hitting what comes at him so it falls in a pile at his feet, clang, clang clang...bowls being washed by people in neat rows. For most of the sixty-five minutes, there is no comment and no other input from the directors. None of the people speak into camera and in fact they don't speak to each other either. As someone in the audience commented, they don't interact at all with another human being - physically or verbally. They sometimes stare into the camera and the camera stares back (or the other way around). The filmmakers ask no questions and get no answers. What we see a lot is exactly - the choreography the dance of the joint actions of people of cutting, cooking, serving, eating, cleaning. Most of this adds up to one message: this is how they do it there. The wonder filled eyes of the camera taking in the 'otherness' of what is before it: images that reinforce what every orientalist has done.

6 At the end of the film we are given a message by way of text: centuries after Sikhism first arrived, the Golden Temple is still one of the rare places in India where people of every caste, class, and kind may sit together and share a simple meal thus erasing all differences and all inequalities. The religious spirit is also reinforced through images that are not about the noise and the 'organized chaos' (words of the filmmaker) of the community kitchen. They are outside the geography of the cooking and eating-places and with the sound in the film dropping by quite a few decibels; they are clearly images that make a huge impact because they communicate peace and beauty. A man in turban, cut off exactly at the waist in the frame gliding gracefully on the water of the pool, solo in his boat, the shimmering gold of the temple reflecting in the water with music in the background, the devotees who stop on their way to somewhere, get off their vehicles and stand, hands folded in front of the temple, men who very calmly remove clothing and enter the water, and then stand very still in the pool. While it is true that the community kitchen and the inspiration behind it, the idea of 'seva' (voluntary service) take up most of the time of the film, it's actually these images here above that make up the 'space' or provide for the context and setting of 'seva'. The choice of placing one such image (man in prayer in the pool) and not one of the kitchen as an accompaniment to the text of the synopsis in the brochure is telling. So, the film in fact conveys more meaning than the title 'Himself, he cooks' suggests.

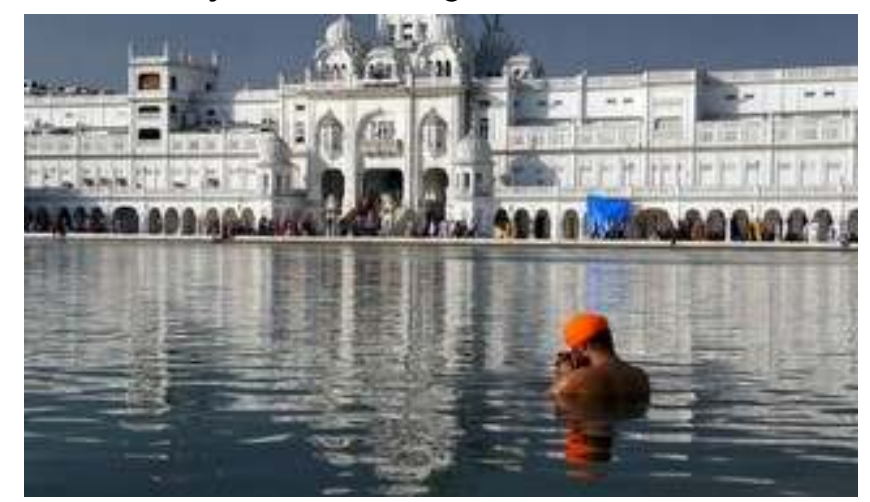

7 Yet one of the filmmakers says 'Sikhisim is about the langar' (the community kitchen) at the time of the $\mathrm{Q}$ and $\mathrm{A}$. The brochure says he is a cook by profession. He is so calm 
and sounds so sure of himself when he makes this statement that no one asks him how he did his research. I ask him a related question. I ask him while he was in the Golden Temple, did he see the rooms devoted to death, violence and martyrdom in the precincts of the temple? These too are interpreted as images of 'seva', or voluntary service by some Sikhs. Only they are not about feeding, but about getting killed and killing people for the greater good of the community. The images of the dead bodies on display are of people who were considered terrorists by some in the early 1980's because they willingly gave up their lives in exchange for taking others. Some of them were killed in the temple itself when the Indian army stormed it in 1984.Their photos with bullet wounds through their heads, eyes and every other part of their bodies are difficult to ignore since they are placed in the outer rooms, very close to the entrance, and presented 'museum style' to the visitors entering the temple. The filmmakers say yes they saw them and that their idea was to focus on the gestures and the choreography of the kitchen 'seva'. To focus on the elements of water, fire and metal. challenge the gross inequalities in Hinduism. And since this is what I saw in my family and community, I believed them. Now, many years later, I see the same message in this film. I moved to the Netherlands a decade ago and began to work on projects in and about India. It was on one of my research trips that I learned that there are outcasts also in Sikhism. That not so far from the Golden Temple, there are Sikh temples with separate entrances and water sources for the outcast and untouchable Sikhs. I asked the filmmakers while they were making this film in India, did anyone Sikh or non-Sikh ever mention these outcasts or untouchables within Sikhism and did they know about it?

They said no.

The filmmakers tell us they see thousands of people making a pilgrimage to the temple to purify themselves. They don't say of what. So we never find out what the images of devotees taking a dip in the pond are about. Could they be of ritual cleansing? The images of the film show several people involved almost round the clock in the cleaning, 
polishing and washing of the temple along with the washing of the utensils. The filmmaker describes after the screening how the plates are washed seven times each. Thousands and thousands of them all day long. The people in the film look like they are purifying the place along with themselves. But again we don't know why this absolute obsession with washing inside the temple walls, while just outside, the city of Amritsar, like any Indian city cries out for some attention to the most basic cleanliness.

I understand it is important to tell inspiring stories about India. I understand also that making poetic images and 'leaving it to the viewer to decide' makes us sound civilized, liberal and democratic. However, we need to be aware that such images and the selective stories they tell could propagate the orientalist view of India. The magic of it, the wonder of it, incredible India and not in the least 'the shining India'. It is plain to any eye - outsider and insider - that the beauty and the horrors of India are entwined together. To rise above definitions in terms of either/or but to engage in and/and is where the challenge as well as the inspiration lies. However, the framing of this particular film and the place it has in this festival invite us to join in the choreography of the community kitchen and marvel at the wonder that is India. It is a reminder that even in this day and age the idea of the 'exotic orient' in our imaginations is alive and well.

May 2012

\section{AUTHOR}

NANDINI BEDI

Chitra Katha Productions, Amsterdam 